УДК 371.134: 811.1/.2 + 81’24 (045)К

Шарий Дмитро Юрійович

студент

Навчально-науковий інститут іноземних мов

Черкаського національного університету імені Богдана Хмельницького, м. Черкаси, Україна

dimashariy92@mail.ru

\title{
СУЧАСНІ ПІДХОДИ ДО ВИКОРИСТАННЯ ІНФОРМАЦЙНИХ ТЕХНОЛОГІЙ У НАВЧАННІ АНГЛІЙСЬКОЇ МОВИ МАЙБУТНІХ ФІЛОЛОГІВ
}

\begin{abstract}
Анотація. Статтю присвячено висвітленню проблеми сучасних підходів до використання інформаційних технологій у навчанні англійської мови майбутніх філологів. Використання зазначених технологій у процесі формування професійної компетентності студентів лінгвістичних спеціальностей зумовлене необхідністю модернізації освіти й розроблення нових стратегій іiі розвитку, а також реалізації обгрунтованих змін стратегії вищої освіти. У статті розглядаються такі аспекти використання мультимедійних засобів у навчальному процесі, як самостійна робота студентів, навчання різних видів мовленнєвої діяльності, всебічний контроль під час занять з англійської мови. Увагу зосереджено на необхідності використання інформаційних технологій для підвищення ефективності процесу навчання.
\end{abstract}

Ключові слова: інформаційні технології; мультимедія-засоби; професійна компетентність; освітня система; освітнє середовище.

\section{1. ВСТУП}

Постановка проблеми. У сучасному світі, де сучасні мультимедійні засоби й інформаційні технології (IT) посідають значне місце майже в усіх галузях людської діяльності, звертається увага на значний вплив цих технологій на навчання майбутніх філологів. Вони майже щодня працюють із великим обсягом інформації у вигляді відомостей, доповідей, звітів, оглядів тощо. Цю інформацію слід редагувати, форматувати, організовувати згідно поставленого завдання, тому фахівцям-філологам слід мати сформовані навички й уміння роботи з комп'ютерною технікою, програмним забезпеченням і сучасними носіями інформації. Проте, не зважаючи на стрімкий розвиток сучасних IT, їх інтеграція в українську систему освіти відбувається дещо повільно і ще не здобула масового поширення. Саме зазначена проблема й зумовлює актуальність цієї теми.

Аналіз останніх досліджень і публікацій. Різні аспекти досліджуваної проблеми висвітлені у працях цілої когорти науковців. Зокрема, у педагогічній літературі описано методи використання IT на концептуальному рівні (Г. Воробйов, А. Ракітов, Є. Семенюк й ін.), у гносеологічному аспекті (І. Агешин, В. Біблер, Л. Землякова, А. Лосев й ін.), як чинник формування професійного типу особистості шляхом засвоєння норм, правил, цінностей інформаційного суспільства (Г. Воробйов, А. Сршов, В. Монахов й ін.), у контексті технічних навичок і вмінь роботи 3 інформацією (Є. Смирнов, А. Яглом, І. Мелик-Гайназян й ін.). Також багато досліджень було присвячено проблемам проектно-рефлексивного підходу до формування навичок i вмінь використання IT за допомогою програми INTEL «Навчання для майбутнього» (Н. Касаткіна, Н. Морзе, Б. Невзоров й ін.), дослідженню інформаційно-динамічного навчального середовища як чинника розвитку вмінь використання IT майбутніми педагогами (Н. Симзінцева), дослідженню когнітивного спрямування процесу 
формування вмінь і навичок використання IT майбутніми педагогами (Л. Холяпіна). Попри це, у педагогічній літературі також описано методи використання IT для середньої школи (Б. Гершунський, О. Довгялло, М. Жалдак й ін.), у мовних вищих навчальних закладах (ВН3) (Г. Клейман, С. Маргілус, Р. Нортон й ін.), у немовних ВНЗ (Б. Скіннер, І. Підласий, Р. Тайлер й ін.).

Мета статті. Виявити й обгрунтувати сучасні підходи до використання IT у навчанні англійської мови (AM) майбутніх філологів у профільному навчанні..

\section{2. РЕЗУЛЬТАТИ ДОСЛІДЖЕННЯ}

Не зважаючи на той факт, що проблема навчання АМ посідає чільне місце у навчальному процесі, вона ще не $є$ остаточно розв'язаною і потребує подальших досліджень. Необхідно дослідити сучасні підходи до навчання, структурування навчального процесу з використанням новітніх IT. Нині в кожному ВНЗ є комп'ютерні аудиторії, оснащені мультимедійними проекторами й іншими допоміжними засобами, але не всі викладачі вміють користуватися цими інструментами. Освітня система протягом багатьох десятиліть шукає шляхи вдосконалення роботи зі студентами. Частина викладачів ще продовжує навчання традиційними методами, однак усі погоджуються 3 унеможливленням подальшого розвитку освіти без застосування інноваційних технологій і сучасних підходів до роботи з ними.

IT - це «система методів і способів збирання, накопичення, зберігання, пошуку, передавання, опрацювання й презентування інформації за допомогою комп'ютерів і комп'ютерних ліній зв'язку» $[1,90]$. Застосування комп'ютерів на уроках АМ істотно підвищує інтенсивність освітнього процесу. Інтерактивне навчання за допомогою навчальних комп'ютерних програм сприяє реалізації цілого комплексу методичних, педагогічних, дидактичних, психологічних принципів, робить процес навчання цікавішим. За допомогою такого способу навчання створюються умови, за яких ураховується темп роботи кожного студента. Наразі розвивається ціннісно-смислова сфера майбутніх філологів, збільшується їхня пізнавальна діяльність, що, безсумнівно, сприяє ефективному підвищенню рівня знань і вмінь. Утім слід пам'ятати, що комп'ютер не може замінити викладача в навчальному процесі. Тут необхідним $є$ ретельне планування часу роботи за комп'ютером, використовувати його лише тоді, коли цього вимагає освітній процес.

Отже, «упровадження IT сприяє досягненню основної мети модернізації освіти поліпшенню якості навчання, збільшенню доступності освіти, забезпеченню гармонійного розвитку особистості, котра орієнтується в інформаційному просторі й залучена до інформаційно-комунікаційних можливостей сучасних технологій і володіє інформаційною культурою» $[3,68]$.

3 моменту появи таких перших мультимедійних засобів навчання, як магнітофон, діапроектор, кінопроектор, обладнання лінгафонних кабінетів, уможливлюється одночасне використання декількох інформаційних середовищ: графіки, тексту, відео, фотографії, анімації, звукових ефектів, високоякісного звукового супроводу $[7,85]$. Останнім часом технічний прогрес досягнув значних висот i, разом із тим, з'явилися нові підходи до використання цих мультимедія-засобів.

Серед сучасних підходів до застосування IT на заняттях з АМ можна виокремити використання різних відеоматеріалів лінгвокраїнознавчого характеру, електронних словників, текстів для аудіювання, створення проектів, мультимедійних презентацій тощо. Не менш корисним способом використання IT $є$ створення сайтів, публікацій, мультимедійних курсів, розроблення та створення дидактичного матеріалу, ведення телемосту із застосуванням веб-камер, використання Інтернет-ресурсів тощо. 
Різні аспекти використання мультимедійних засобів у царині освіти обмежуються колом питань використання технічних засобів навчання (ТЗН) або комп'ютерноорієнтованого засобу навчання «нового» покоління, котрому притаманні такі характерні ознаки [6, 93]: можливість поєднання інформації, представленої у різних формах (текст, звук, графіка, відео, анімація) й інтерактивний режим роботи 3 інформацією [11]. Оскільки інформація надається в різних формах, це підвищує досвід користувача й дозволяє швидше засвоювати інформацію.

Існує типологія інноваційних підходів до навчання, у якій виокремлено два основних типи інновацій [12, 169]: 1) інновації-модернізації; 2) інноваціїтрансформації, які відповідають репродуктивній i проблемній орієнтації технологічного підходу в освітньому процесі. Розглянемо докладніше кожний iз виокремлених типів.

Інновації-модернізащії уможливлюють видозмінення навчального процесу i сприяють досягненню гарантованих результатів у межах його традиційної репродуктивної орієнтації. Їх підгрунтям $є$ технологічний підхід, спрямований на поглиблення студентами знань й орієнтований на високоефективне репродуктивне навчання. Інноваціï-трансформації здатні цілком змінити навчальний процес. Вони впроваджуються 3 метою забезпечення його дослідницького характеру, організації пошукової навчально-пізнавальної діяльності студентів. Відповідний пошуковий підхід до навчання зосереджується, насамперед, на формуванні у студентів досвіду самостійного пошуку нових знань, їх використання в нових умовах, формування досвіду творчої діяльності в поєднанні з відпрацюванням ціннісних орієнтацій [12, 170].

Сучасні IT відіграють важливу роль у сучасній освіті. Використання комп'ютерів у навчальній i позанавчальній діяльності дозволяє розв'язати такі проблеми: індивідуалізацію і диференціацію навчання; мотивацію навчання; запобігання труднощів у роботі з друкованими виданнями; дефіцит часу.

IT $\epsilon$ простими у застосуванні й викладач не може не використовувати їх на своїх заняттях для формування мовної компетенції майбутніх філологів. IT дозволяють використовувати нові форми й методи навчання для розвитку мислення майбутніх філологів.

Комп'ютер найкраще «вписується» до структури навчального процесу, найповніше відповідає дидактичним вимогам і максимально наближає процес навчання АМ до реальних умов. Новітні технології суттєво розширюють можливості викладачів індивідуалізувати навчання, активізувати пізнавальну діяльність майбутніх філологів, адаптувати процес навчання до індивідуальних особливостей студентів.

Нині існує принципово новий підхід, який передбачає використання комп'ютерних технологій у навчанні АМ майбутніх філологів. Цей підхід [4, 131]: а) базується на широкому міжкультурному спілкуванні; б) має своїм підгрунтям реальні дослідницькі методи; в) сприяє розвитку рідної мови й оволодінню АМ, коли йдеться про участь у міжнародних проектах; г) допомагає набути нові супутні навички, котрі можуть виявитися корисними в подальшому житті, у тому числі й навички користування комп'ютерною технікою й IT.

Комп'ютер є інструментом, який організовує самостійну роботу студентів і керує нею, особливо у процесі тренувальної роботи 3 мовним матеріалом. Використання комп'ютерів на заняттях з АМ значно підвищує інтенсивність навчального процесу [5, 299]. Під час навчання з використанням сучасних IT засвоюється значно більший обсяг виучуваного матеріалу, аніж за традиційного навчання. Попри це, майбутні філологи набагато якісніше оволодівають фонетичними навичками й уміннями за допомогою аудіозаписів автентичного мовлення. 
Специфіка предмету «Практичний курс англійської мови» полягає в тому, що основним компонентом змісту навчання АМ $є$ навчання різних видів мовленнєвої діяльності (МД): говорінню, аудіюванню, читанню, письму. Слід розуміти, що навчати МД можна лише в живому процесі спілкування, а для цього потрібен партнер. Комп'ютерна програма, компакт-диск, якими б інтерактивними вони наразі не були, можуть забезпечити лише квазіспілкування (тобто спілкування 3 машиною). Виключенням $є$ лише телекомунікації, коли студенти вступають у живий діалог (писемний чи усний) із реальним партнером - носієм мови [2, 151].

За допомогою мультимедійних навчальних програм уможливлюється створення майбутніми філологами персонального середовища для спілкування АM, пошук однодумців, яких цікавлять аналогічні проблеми й які можуть бути представниками різних держав, наприклад, носіями мови, що сприятиме не лише якнайглибшому іiі оволодінню, а й отриманню від них нової інформації [10, 17].

Попри це, персональний комп'ютер може бути використаний викладачем для розв'язання багатьох дидактичних завдань протягом заняття: виклад інформації у різних формах; формування у студентів загальних і спеціальних знань і вмінь 3 того чи іншого предмету; контроль, оцінювання й корекція результатів навчання; організація індивідуального і групового навчання; керування процесом навчання. Комп'ютер можна використовувати на всіх етапах навчального процесу: для пояснення нового матеріалу; закріплення; повторення; контролю [8, 23].

Комп'ютер забезпечує всебічний контроль едукаційного процесу. У ході його використання уможливлюється досягнення максимально об'єктивного оцінювання. Він дозволяє заощадити навчальний час, оскільки здійснюється одночасна перевірка знань усіх студентів. Це уможливлює приділення більшої кількості часу творчим аспектам роботи.

Мультимедійні кабінети у ВНЗ дозволяють проводити заняття на якісно новому рівні, комп'ютерні презентації допомагають звернути увагу студентів на важливих моментах і створювати наочні образи у вигляді ілюстрацій, схем, діаграм, графічних композицій тощо. Уможливлюється робота 3 програмами Microsoft Word, Microsoft Excel, Microsoft Power Point, використання мультимедійного проектора, пошук у мережі Інтернет.

Інтерес до комп'ютерних програм, які використовуються в навчальному процесі, можна пояснити, насамперед, широким спектром можливостей, котрими вони володіють. Використання комп'ютерних засобів забезпечує велику інформативну базу мовного матеріалу, високу якість наочного матеріалу, підвищує пізнавальну активність студентів. Саме завдяки цьому мультимедійні програми мають значно більше переваг, аніж інші комп'ютерні курси для навчання АМ.

Залежно від дидактичних цілей, можна виокремити такі види комп'ютерних програм [9]: навчальні, тренажери, контролюючі, демонстраційні, імітаційні, довідковоінформаційні, мультимедія-підручники. Найчастіше використовують демонстраційні програми, однією з яких є Microsoft Power Point. Ця програма дозволяє викладачеві самостійно підготувати мультимедійну презентацію до заняття 3 мінімальними затратами часу.

У процесі підготовки презентації створюються умови для розвитку мотивації вивчення АМ, розширюються фонові знання студентів, їх світогляд і поінформованість. Ефективність впливу навчального матеріалу на студентів багато в чому залежить від ступеня й рівня ілюстративності матеріалу. Візуальна насиченість мультимедійних презентацій робить їх яскравими, переконливими і сприяє інтенсифікації процесу засвоєння мовного матеріалу. 
Мультимедійна презентація містить матеріал для спілкування АМ, будучи підгрунтям для монологічного мовлення, тобто уможливлює реалізацію комунікативної функції мови. Вона $є$ ефективним прийомом розвитку й удосконалення монологічного висловлювання, оскільки у процесі свого виступу студенти мають можливість використовувати ключові слова, ілюстрації, схеми, які вони розробили. Це дозволяє робити повідомлення послідовним, розгорнутим, виразним, із достатньою швидкістю, без необгрунтованих пауз між фразами [11].

Як вже було зазначено, програмне забезпечення Microsoft Power Point набуло великого поширення й користується популярністю у користувачів. Інтеграція з іншими програмами дозволяє швидко і якісно створити мультимедійну презентацію, котра крім тексту може включати й комп'ютерну анімацію, картинки, графіки, таблиці, відео та музичний супровід, організовані в єдине середовище.

Перш ніж приступити до підготовки мультимедійної презентації, необхідно обрати тему, визначити кількість і вміст слайдів, а студентам самостійно розподілити між собою рольові функції: спікер - студент, сильний у царині АМ; фахівець 3 IT студент, який добре розбирається у програмі Microsoft Power Point; робоча група - інші студенти, які працюють над створенням фрагментів спільного проекту мультимедійної презентації.

Використовувати мультимедійну презентацію в едукаційному процесі можна на різних етапах заняття. Водночас ії сутність як наочного засобу залишається незмінною, варіюються лише іiї форми, залежно від поставленої мети ії використання. Враховуючи великі дидактичні можливості комп'ютерної презентації знань, уже найближчим часом слід очікувати інтенсивнішого використання мультимедійних презентацій у навчальному процесі [9].

\section{3. ВИСНОВКИ ТА ПЕРСПЕКТИВИ ПОДАЛЬШИХ ДОСЛІДЖЕНЬ}

Як висновок, слід зазначити, що використання сучасних підходів до використання IT у навчанні АМ якісно підвищує професійні навички майбутніх філологів. Це дозволяє видозмінити навчальний процес або повністю перетворити його задля забезпечення його дослідницького характеру. Попри це, нові підходи стимулюють міжкультурне спілкування й водночас забезпечують компетентність фахівців у царині комп'ютерних технологій

Перспективи подальших пошуків у напрямку дослідження вбачаємо в необхідності проаналізувати особливості використання мультимедійних засобів за такими напрямами: дистанційне навчання на основі системного підходу; проектування й конструювання мультимедійних навчальних посібників; проблеми визначення мультимедія в освіті; активізація пізнавальної діяльності студентів в умовах дистанційного навчання.

\section{СПИСОК ВИКОРИСТАНИХ ДЖЕРЕЛ}

1. Азимов Э. Г. Новый словарь методических терминов и понятий (теория и практика обучения языкам) / Э. Г. Азимов, А. Н. Щукин. - М. : ИКАР, 2009. - 448 с.

2. Диброва Е. В. Применение компьютерных технологий в процессе обучения иностранным языкам / Е. В. Диброва, Н. Г. Евтушенко // Новые технологии. - 2009. - № 4 (26). - С. 149-152.

3. Коваленко И. Н. На пути к е-дидактике? / И. Н. Коваленко // Информационные технологии в образовании-2007: сб. науч. трудов участников VII науч.-практ. конф.-выставки 30-31 октября 2007 г. - Ростов н/Д : Ростиздат, 2007. - С. 68-69.

4. Коджаспирова Г. М. Технические средства обучения и методика их использования / Г. М. Коджаспирова, К. В. Петров. - М : Издательский центр «Академия», 2001 - 256 с. 
5. Маслыко Е. А. Настольная книга преподавателя иностранного языка / Е. А. Маслыко, П. К. Бабинская, А. Ф. Будько. - Минск : Вышэйшая школа, 1999. - 522 с.

6. Мультимедиа / [под ред. А. И. Петренко]. - М. : БИНОМ, 1994. - 272 с.

7. Нісімчук А. С. Сучасні педагогічні технології / А. С. Нісімчук, О. С. Падалка, О. Т. Шпак. - К. : Просвіта, 2000. - 368 с.

8. Скаткин М. Н. Активизация познавательной деятельности учащихся в обучении / М. Н. Скаткин. М. : Педагогика, 1995. - 275 с.

9. Сухинина О. С. Теоретические основы и методика использования мультимедийных технологий в обучении иностранным языкам [Электронный ресурс] / О.С. Сухинина // Муниципальное бюджетное общеобразовательное учреждение «Михайловский лицей» Михайловского района Алтайского края : [Сайт]. - Режим доступа : http://mihliceum.ucoz.ru/ publ/stati_uchitelej/metodicheskie_razrabotki_uchitelej/sukhinina_o_s_teoreticheskie_osnovy_i_metodik a_ispolzovanija_multimedijnykh_tekhnologij_v_obuchenii_inostrannym_jazykam/5-1-0-43.

10. Телицына Т. Использование компьютерных программ на уроках английского языка / Т. Телицына, А. Сидоренко // Иностранные языки в школе. - 2002. - № 2. - С. 41-43.

11. Цыганкова Е. А. Использование мультимедийных презентаций при обучении иностранным языкам [Электронный ресурс] / Е. А. Цыганкова // Научно-технические конференции [Сайт]. - Режим доступа : http://science-bsea.narod.ru/2011/it_2011/cygankova_isp.htm.

12. Чермит К. Д. Инновационный подход в обучении информатике как основа формирования профессиональной информационно-технологической компетентности специалиста / К. Д. Чермит, Е. Б. Птущенко, И. П. Субботина // Вестник Адыгейского государственного университета. Серия 3: Педагогика и психология. - 2008. - № 5. - С. 168-171.

Матеріал надійшов до редакиї 17.03.2013 p.

\title{
СОВРЕМЕННЫЕ ПОДХОДЫ К ИСПОЛЬЗОВАНИЮ ИНФОРМАЦИОННЫХ ТЕХНОЛОГИЙ В ОБУЧЕНИИ ИНОСТРАННОМУ ЯЗЫКУ БУДУЩИХ ФИЛОЛОГОВ
}

\author{
Шарый Дмитрий Юрьевич \\ студент \\ Учебно-научный институт иностранных языков \\ Черкасского национального университета имени Богдана Хмельницкого, г. Черкассы, Украина \\ dimashariy92@mail.ru
}

\begin{abstract}
Аннотация. Статья посвящена освещению проблемы использования современных подходов к использованию информационных технологий в обучении английскому языку будущих филологов. Использование указанных технологий в процессе формирования профессиональной компетентности студентов лингвистических специальностей обусловлено необходимостью модернизации образования и разработки новых стратегий его развития, а также реализации обоснованных изменений стратегии высшего образования. В статье рассматриваются такие аспекты использования мультимедийных средств в учебном процессе, как самостоятельная работа студентов, обучение разным видам речевой деятельности, всесторонний контроль во время занятий по английскому языку. Внимание сосредоточено на необходимости использования информационных технологий для повышения эффективности процесса обучения.
\end{abstract}

Ключевые слова: информационные технологии; мультимедиа-средства; профессиональная компетентность; образовательная система; образовательная среда.

\section{MODERN APPROACHES TO THE USAGE OF INFORMATION TECHNOLOGIES IN TEACHING ENGLISH TO FUTURE PHILOLOGISTS}




\author{
Dmytro Yu. Sharyi \\ student \\ Educational-Scientific Institute of Foreign Languages \\ Bohdan Khmelnytsky National University at Cherkasy, Cherkasy, Ukraine \\ dimashariy92@mail.ru
}

\begin{abstract}
The article deals with the highlighting of the problem of modern approaches to information technologies usage in teaching English to future philologists. The usage of these technologies in the process of formation of professional competence of students of linguistic specialties is conditioned by the necessity of education modernization and working out new strategies of its development as well as realization of grounded changes in higher education strategies. Such aspects of multimedia technologies usage in the educational process as students' individual work, teaching different kinds of speech activity, control at English classes are studied in the paper. Attention is focused on the necessity of information technologies usage for increasing effectiveness of the educational process.
\end{abstract}

Keywords: informational technologies; multimedia means; professional competence; educational system; educational environment.

\title{
REFERENCES (TRANSLATED AND TRANSLITERATED)
}

1. Azimov E. G. New Dictionary of Methodical Terms and Notions (Theory and Practice of Teaching Languages) / E. G. Azimov, A. N. Shchukin. - M. : IKAR, 2009. - 448 p. (in Russian)

2. Dibrova Ye. V. The Usage of Computer Technologies in the Process of Teaching Foreign Languages / Ye. V. Dibrova, N. G. Yevtushenko // Novye tehnologii. - 2009. - № 4 (26). P. 149-152. (in Russian)

3. Kovalenko I. N. On the Way to E-Didactics? / I. N. Kovalenko // Information Technologies in Education-2007: Digest of Scientific Works of the Participants of the 7th Theoretical-and-Practical Conference-Exhibition, 30-31 October 2007. - Rostov-on-Don : Rostizdat, 2007. - P. 68-69. (in Russian)

4. Kodzhaspirova G. M. Technical Means of Education and Methods of Their Usage / G. M. Kodzhaspirova, K. V. Petrov. - M : Izdatel'skij centr «Akademiya», 2001. - 256 p. (in Russian)

5. Maslyko Ye. A. English Lecturer's Reference Book / Ye. A. Maslyko, P. K. Babinskaya, A. F. Bud'ko. - Minsk : Vyshejshaya shkola, 1999. - 522 p. (in Russian)

6. Multimedia / [Ed. A. I. Petrenko]. - M. : BINOM, 1994. - 272 p. (in Russian)

7. Nisimchuk A. S. Modern Pedagogical Technologies / A. S. Nisimchuk, O. S. Padalka, O. T. Shpak. - K. : Prosvita, 2000. - 368 p. (in Ukrainian)

8. Skatkin M. N. Activization of Pupils' Cognitive Activity in Education / M. N. Skatkin. - M. : Pedagogika, 1995. - 275 p. (in Russian)

9. Suhinina O. S. Theoretical Bases and Methods of Multimedia Technologies Usage in Teaching Foreign Languages [online] / O. S. Suhinina // Municipal'noe bjudzhetnoe obshcheobrazovatel'noe uchrezhdenie «Mihajlovskij licej» Mihajlovskogo rajona Altajskogo kraja. - Available from: http://mihliceum.ucoz.ru/publ/stati_uchitelej/metodicheskie_ razrabotki_uchitelej/sukhinina_o_s_teoreticheskie_osnovy_i_metodika_ispolzovanija_multimedij nykh_tekhnologij_v_obuchenii_inostrannym_jazykam/5-1-0-43. (in Russian)

10. Telicyna T. Usage of Computer Programs at English Lessons / T. Telicyna, A. Sidorenko // Inostrannyje jazyki v shkole. - 2002. - № 2. - P. 41-43. (in Russian)

11. Cygankova Ye. A. Usage of Multimedia Presentations in Teaching Foreign Languages [online] / Ye. A. Tsygankova // Nauchno-tehnicheskie konferencii [Site]. - Available from: http://sciencebsea.narod.ru/2011/it_2011/cygankova_isp.htm. (in Russian)

12. Chermit K. D. Innovational Approach in Teaching Informatics as a Basis of Formation of Specialist's Professional Information-and-Technology Competence / K. D. Chermit, Ye. B. Ptushchenko, I. P. Subbotina // Vestnik Adygejskogo gosudarstvennogo universiteta. Seriya 3: Pedagogika i psihologija. - 2008. - №5. - P. 168-171. (in Russian) 